\title{
PENGARUH FAKTOR PELUANG UNTUK BELAJAR DAN KEPERCAYAAN EFIKASI TERHADAP PENGETAHUAN MATEMATIK UNTUK PENGAJARAN
}

\section{(THE INFLUENCE OF OPPORTUNITIES TO LEARN AND EFFICACY BELIEF FACTOR TOWARDS MATHEMATICAL KNOWLEDGE FOR TEACHING)}

\author{
Muhamad Nazri Abdul Rahman*, Sharifah Norul Akmar Syed Zamri \\ and Leong Kwan Eu \\ Faculty of Education, Universiti Malaya, Jalan Universiti, \\ 50603 Kuala Lumpur, Malaysia \\ *Corresponding author: nazri1979@gmail.com
}

Publication date: 30 June 2020

To cite this article: Muhamad Nazri Abdul Rahman, Sharifah Norul Akmar Syed Zamri, \& Leong Kwan Eu. (2020). Pengaruh faktor peluang untuk belajar dan kepercayaan efikasi terhadap pengetahuan matematik untuk pengajaran. Asia Pacific Journal of Educators and Education, 35(1), 111-135. https://doi.org/10.21315/apjee2020.35.1.7

To link to this article: https://doi.org/10.21315/apjee2020.35.1.7

\begin{abstract}
The present study investigates the influence of opportunities to learn (OTL) and mathematics teaching efficacy beliefs (MTEB) towards mathematical knowledge for teaching (MKT). Using a structured questionnaire together with paper and pencil test adapted from the literature reviewed, data were collected from 187 pre-service elementary teachers in Institute of Teacher Education (ITE) Malaysia. Data were analysed using SmartPLS 3.0. The result of the structural equation model indicated that both OTLPracticum $(\beta=0.395, p<0.001)$ and OTL-Program $(\beta=0.324, p<0.001)$ was positively related to $M K T$. The second regression analysis was to examine the impact of mathematics teaching efficacy belief on the MKT. The results showed that mathematics teaching outcome expectancy belief (MTOEB) $(\beta=0.322, p<0.001)$ was positively related to $M K T$, whereas personal mathematics teaching efficacy belief $(\beta=0.017, p>0.1)$ was not related to MKT. Overall, the belief and OTL factors explaining a total of 54\% variance in MKT. Implications from these findings to the successful teacher's education program implementation in Malaysia were further elaborated.
\end{abstract}

(C) Penerbit Universiti Sains Malaysia, 2020. This work is licensed under the terms of the Creative Commons Attribution (CC BY) (http://creativecommons.org/licenses/by/4.0/). 
Keywords: Opportunities to learn, efficacy belief, mathematical knowledge for teaching, personal mathematics teaching efficacy belief, mathematics teaching outcome expectancy belief

\begin{abstract}
Abstrak: Kajian ini dijalankan untuk menguji pengaruh faktor peluang untuk belajar (PUB) dan kepercayaan efikasi pengajaran matematik (KEPM) terhadap pengetahuan matematik untuk pengajaran (PMUP). Data telah dikumpul daripada 187 orang guru pra perkhidmatan di Institut Pendidikan Guru (IPG) Malaysia dengan menggunakan borang soal selidik beserta ujian pensel dan kertas yang diadaptasi daripada kajian terdahulu. Analisis data telah dijalankan menggunakan perisian SmartPLS 3.0. Dapatan daripada analisis model persamaan berstruktur yang telah dijalankan menunjukkan kedua-dua faktor PUBPraktikum $(\beta=0.395, p<0.001)$ dan PUB-Program $(\beta=0.324, p<0.001)$ mempunyai perkaitan yang positif dengan PMUP. Analisis regresi yang kedua adalah untuk menguji pengaruh faktor kepercayaan efikasi pengajaran matematik terhadap PMUP. Dapatan menunjukkan Kepercayaan Jangkaan Hasil Pengajaran Matematik (KJHPM) $(\beta=0.322, p$ $<0.001)$ mempunyai perkaitan yang positif dengan PMUP, manakala faktor Kepercayaan Efikasi Pengajaran Matematik Peribadi (KEPMP) $(\beta=0.017, p>0.1)$ pula didapati tidak mempunyai perkaitan dengan PMUP. Secara keseluruhan, kedua-dua faktor kepercayaan dan PUB menjelaskan sebanyak 54\% varians di dalam PMUP. Implikasi kajian ini ke atas kejayaan pelaksanaan program pendidikan guru di Malaysia telah dihuraikan dengan lebih lanjut.
\end{abstract}

Kata kunci: Peluang untuk belajar, kepercayaan efikasi, pengetahuan matematik untuk pengajaran, kepercayaan efikasi pengajaran matematik peribadi, kepercayaan jangkaan hasil pengajaran matematik

\title{
PENGENALAN
}

Guru merupakan individu yang bertanggungjawab melaksanakan proses pengajaran dan pembelajaran (PdP) berkesan bagi memastikan pelajar menguasai setiap kemahiran yang terkandung di dalam kurikulum matematik (Shirvani, 2015). Pengetahuan yang dimiliki oleh guru berperanan memastikan pelaksanaan aktiviti PdP yang berkesan dan seterusnya mampu meningkatkan prestasi matematik pelajar (Goos, 2013). Tahap penguasaan pengetahuan kandungan dan pedagogi matematik yang rendah dalam kalangan guru secara tidak langsung akan menyumbang kepada pelaksanaan proses PdP matematik yang kurang berkesan (Ball, Thames, \& Phelps, 2008).

Pengetahuan Matematik untuk Pengajaran (PMUP) adalah konsep tentang pengetahuan matematik yang diperlukan oleh guru untuk mengajar dengan berkesan. Ia termasuklah menilai tindak balas pelajar, menjawab soalan yang dikemukakan 
oleh pelajar, menyediakan tugasan dan membuat rancangan pengajaran (Ball et al., 2008). Menurut Austin (2015) konsep PMUP yang dibangunkan oleh Ball et al. (2008) adalah pembinaan pelbagai dimensi yang terdiri daripada pengetahuan kandungan (PK) dan pengetahuan pedagogi kandungan (PPK).

Kajian Teacher Education Development Study in Mathematics (TEDS-M) telah dijalankan oleh International Association for the Evaluation of Educational Achievement (IEA) pada tahun 2008 ke atas 17 buah negara bagi menyediakan maklumat berkaitan pengetahuan bakal guru sekolah rendah dan menengah rendah sepanjang mengikuti program pendidikan guru (Tatto et al., 2012). Malaysia merupakan salah sebuah negara yang terlibat dalam kajian tersebut. Seramai 524 orang guru pra perkhidmatan sekolah rendah dan 388 orang guru pra perkhidmatan menengah rendah yang sedang berada di tahun akhir pengajian terlibat dalam kajian tersebut (Leong, Chew, \& Abdul Rahim, 2015). Dapatan kajian tersebut yang dikeluarkan pada tahun 2012 menunjukkan tahap penguasaan PMUP dalam kalangan guru pra perkhidmatan di Malaysia adalah rendah (Tatto et al., 2012). Selain daripada dapatan kajian TEDS-M pada tahun 2008 seperti yang dijelaskan oleh Leong et al. (2015), kajian oleh Mohd Yusof dan Zakaria (2010), dan Zulkpli, Mohamed dan Abdullah (2017) turut mendapati tahap penguasaan pengetahuan guru matematik di Malaysia adalah rendah.

Tahap penguasaan PMUP yang rendah dalam kalangan guru juga memberi kesan terhadap kejayaan sesuatu program pendidikan guru yang disediakan. Menurut Tatto, Rodriguez dan Lu (2015), pengetahuan yang dimiliki oleh guru pra perkhidmatan di akhir kursus perguruan merupakan indikator utama kejayaan program pendidikan guru yang telah diikuti. Pihak Kementerian Pendidikan Malaysia (KPM) telah memperuntukkan sejumlah wang yang banyak setiap tahun kepada Institut Pendidikan Guru (IPG) bagi memastikan program pendidikan guru yang ditawarkan mampu melahirkan guru yang berkualiti (Kementerian Kewangan Malaysia, 2017). Sekiranya tahap PMUP dalam kalangan guru di akhir kursus perguruan adalah rendah, ini menggambarkan program pendidikan guru yang diikuti adalah kurang berkesan bagi melahirkan guru yang kompeten dan seterusnya menyebabkan pulangan ke atas pelaburan yang telah dibuat oleh pihak KPM tidak berbaloi. Bagi menangani isu berkenaan, terdapat keperluan bagi menjalankan kajian untuk mengenal pasti faktor yang mempengaruhi penguasaan PMUP dalam kalangan guru pra perkhidmatan di IPG.

Berdasarkan analisis kritikal yang telah dijalankan, didapati terdapat beberapa saranan daripada pengkaji terdahulu berkaitan pemboleh ubah yang boleh diuji bagi menjelaskan faktor yang mempengaruhi PMUP. Antaranya, Austin (2015) mencadangkan supaya konstruk Kepercayaan Efikasi Pengajaran Matematik 
Peribadi (KEPMP) diuji. Selain itu, Mohd Tajudin, Chinnappan dan Saad (2017) pula mencadangkan supaya PPK guru turut dikaitkan dengan peluang untuk belajar (PUB) strategi pengajaran yang inovatif. Simsek dan Boz (2016) turut mencadangkan supaya faktor-faktor seperti jantina, umur dan peluang mengikuti latihan mengajar turut diambil kira. Berdasarkan saranan-saranan yang diberikan oleh pengkaji terdahulu, kajian ini akan menguji pengaruh faktor Kepercayaan Efikasi Pengajaran Matematik (KEPM) dan PUB terhadap PMUP.

Justeru, berasaskan model PMUP oleh Ball et al. (2008), kajian ini akan menguji model konseptual kajian dengan mengintegrasikan model PMUP, Teori Kognitif Sosial oleh Bandura (1989a; 1989b) serta beberapa set pemboleh ubah berkaitan PUB yang diperolehi daripada kajian literatur bagi mengkaji pengaruh faktor PUB dan kepercayaan efikasi terhadap PMUP dalam kalangan guru pra perkhidmatan di IPG.

\section{KERANGKA TEORI DAN MODEL KAJIAN}

Teori yang menjadi asas kepada kajian ini adalah model PMUP oleh Ball et al. (2008). Teori ini dipilih berdasarkan kesesuaiannya mengukur tahap penguasaan PK dan PPK matematik dalam kalangan guru pra perkhidmatan. Teori PMUP turut digunakan oleh pengkaji-pengkaji terdahulu bagi mengukur tahap penguasaan pengetahuan guru matematik. Antaranya adalah kajian oleh Buchholtz (2017) yang mengkaji tentang persepsi guru pra perkhidmatan berkaitan kursus yang mereka ikuti dan kesannya terhadap PPK matematik. Selain itu, Norton (2017) turut menggunakan model PMUP bagi mengkaji hubungan di antara tahap keyakinan dengan PK dan PPK matematik dalam kalangan guru pelatih. Pengkaji-pengkaji lain yang turut menggunakan model PMUP dalam kajian mereka adalah Shahbari (2017), Qian dan Youngs (2016), Pape et al. (2015), Kleickmann et al. (2013; 2015), Venkat dan Spaull (2015), Hine (2015), Leong et al. (2015), Mosvold dan Fauskanger (2014), Thanheiser, Browning, Edson, Kastberg dan Lo (2013), dan Tatto et al. (2012). PMUP meliputi tiga kategori pengetahuan yang berkaitan dengan PK guru:

1. Pengetahuan Kandungan Bersama (PKB), iaitu pengetahuan dan kemahiran matematik yang tidak hanya dikhususkan untuk mengajar matematik.

2. Pengetahuan Kandungan Khusus (PKK), iaitu pengetahuan dan kemahiran matematik yang unik khusus untuk mengajar matematik.

3. Pengetahuan Kandungan Horizon (PKH), iaitu kesedaran tentang perkaitan di antara setiap topik dalam matematik (Ball et al., 2008). 
Selain itu, PMUP juga terdiri daripada tiga kategori pengetahuan yang berkaitan dengan PPK:

1. Pengetahuan berkaitan Kandungan dan Pelajar (PKPel), iaitu pengetahuan berkaitan pemikiran matematik pelajar, yang memerlukan interaksi di antara pemahaman matematik yang spesifik dan pemahaman tentang pemikiran matematik pelajar.

2. Pengetahuan berkaitan Kandungan dan Pengajaran (PKP), iaitu pengetahuan berkaitan reka bentuk pengajaran, yang memerlukan interaksi di antara pemahaman matematik dan pemahaman berkaitan isu pedagogi yang mempengaruhi pembelajaran pelajar.

3. Pengetahuan berkaitan Kandungan dan Kurikulum (PKK), iaitu pengetahuan berkaitan bahan pengajaran dan program (Ball et al., 2008).

Kajian ini turut mengintegrasikan teori berkaitan kepercayaan efikasi guru. Teori Kognitif Sosial oleh Bandura (1989a; 1989b) telah dipilih untuk digunakan dalam kajian ini. Teori tersebut dipilih kerana kesesuaian pemboleh ubah-pemboleh ubahnya untuk menjelaskan pengaruh faktor kepercayaan efikasi pengajaran matematik terhadap penguasaan PK dan PPK matematik guru pra perkhidmatan. Ini adalah berdasarkan dapatan kajian oleh Ekstam, Korhonen, Linnanmäki dan Aunio (2017), Norton (2017), Oppermann, Anders dan Hachfeld (2016), Austin (2015), dan Swars, Smith, Smith dan Hart (2009). Menurut Ekstam et al. (2017), terdapat hubungan tidak langsung di antara kepercayaan efikasi guru dengan PK. Sementara itu, dapatan daripada kajian oleh Norton (2017) pula mendapati terdapat hubungan yang signifikan di antara tahap keyakinan guru dengan PK matematik. Kajian-kajian oleh Oppermann et al. (2016), Austin (2015) dan Swars et al. (2009) juga turut mendapati bahawa terdapat perkaitan di antara kepercayaan efikasi dengan pengetahuan guru.

Selain daripada model PMUP dan kepercayaan efikasi guru, pengkaji juga akan turut menguji kesan faktor peluang untuk belajar (PUB) atau lebih dikenali sebagai Opportunity to Learn (OTL). Faktor ini telah dipilih berdasarkan dapatan kajian-kajian terdahulu yang mendapati faktor PUB berperanan mempengaruhi penguasaan PK dan PPK guru. Antaranya adalah kajian oleh Konig et al. (2017), Dunekacke, Jenben, Eilerts dan Blomeke (2016), Qian dan Youngs (2016), Tatto, Rodriguez dan Lu (2015), dan Adamson (2012). Namun begitu, pengaruh faktor PUB terhadap penguasaan pengetahuan guru daripada kajian terdahulu kebanyakannya tertumpu dalam kalangan guru bahasa di luar negara, khususnya di Eropah. 
Setelah meneliti literatur kajian dan mengenal pasti teori yang berkaitan dan bersesuaian, pengkaji membentuk model kajian seperti yang terdapat dalam Rajah 1. Pemboleh ubah kepercayaan efikasi diwakili oleh pemboleh ubah Kepercayaan Efikasi Pengajaran Matematik Peribadi (KEPMP) dan Kepercayaan Jangkaan Hasil Pengajaran Matematik (KJHPM). Pemboleh ubah-pemboleh ubah PUB pula terdiri daripada peluang untuk menjalani latihan mengajar (PUBPraktikum) dan peluang untuk mengikuti program pendidikan guru yang koheren (PUB-Program).

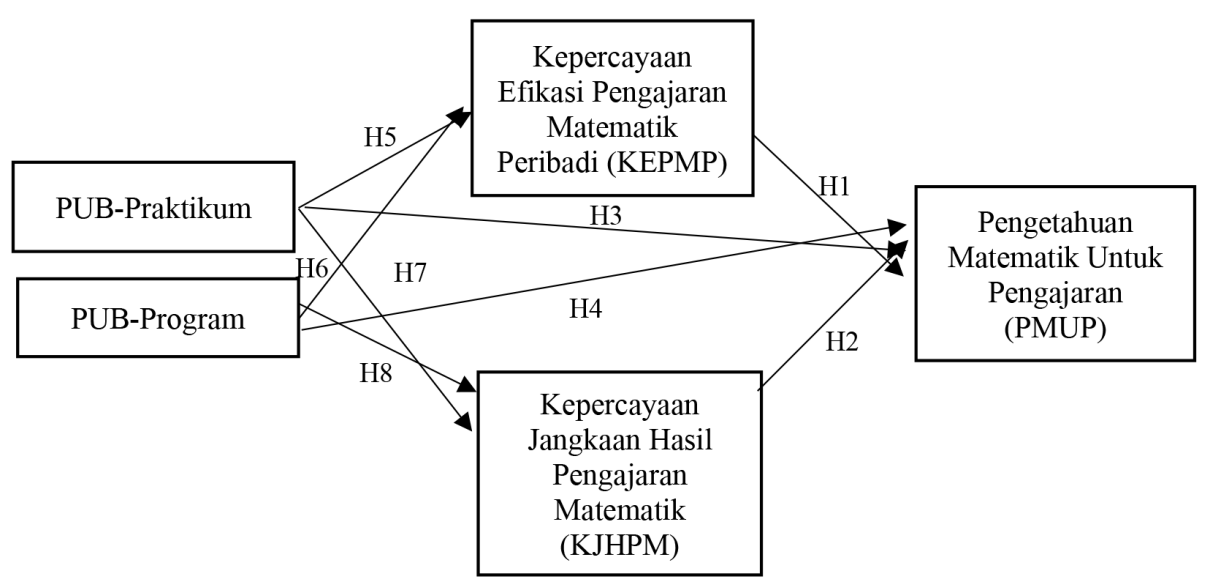

Rajah 1. Model kajian

Kajian yang telah dijalankan oleh Austin (2015) telah membuktikan bahawa faktor KEPMP mempengaruhi penguasaan PMUP. Selain itu, kajian oleh Shi (2016) dan Swars et al. (2009) juga turut mendapati faktor KEPMP dan KJHPM mempengaruhi penguasaan PPK matematik guru. Kajian oleh Swars, Hart, Smith, Smith dan Tolar (2007) turut mendapati terdapat hubungan yang signifikan di antara KEPMP dan KJHPM dengan penguasaan PK matematik guru pra perkhidmatan. Justeru kajian ini akan mengkaji pengaruh faktor KEPM terhadap PMUP dalam kalangan guru pra perkhidmatan di IPG.

H1: Kepercayaan Efikasi Pengajaran Matematik Peribadi (KEPMP) mempunyai kesan langsung yang signifikan dengan penguasaan PMUP

H2: Kepercayaan Jangkaan Hasil Pengajaran Matematik (KJHPM) mempunyai kesan langsung yang signifikan dengan penguasaan PMUP 
Kajian lepas membuktikan bahawa pemboleh ubah PUB mempengaruhi penguasaan PK dan PPK guru. Antaranya, kajian oleh Konig et al. (2017) ke atas bakal-bakal guru bahasa Inggeris sekolah menengah mendapati PUB kandungan dan PUB latihan mengajar telah mempengaruhi penguasaan PPK mereka. Analisis regresi menunjukkan PUB dapat meramal skor ujian PPK guru pelatih secara positif iaitu dengan nilai $\beta$ bersamaan $0.28(p<0.01)$ bagi PUB kandungan, dan nilai $\beta$ bersamaan $0.29(p<0.01)$ bagi PUB latihan mengajar (praktikum). Selain itu, kajian oleh Akkoç dan Yeşildere (2010) turut mendapati PUB latihan mengajar (praktikum) mempengaruhi penguasaan PPK guru secara signifikan.

Kajian oleh Kleickmann et al. (2013) dan Tatto et al. (2012) ke atas guru-guru pra perkhidmatan juga mendapati peluang untuk mengikuti program pendidikan guru koheren (PUB-Program) turut mempengaruhi penguasaan PK dan PPK guru. Ini jelas menunjukkan bahawa PUB merupakan faktor penting yang mempengaruhi penguasaan pengetahuan dan pencapaian akademik bakal guru. Justeru kajian ini akan turut mengkaji pengaruh PUB terhadap penguasaan PMUP dalam kalangan guru pra perkhidmatan di IPG.

H3: Peluang untuk menjalani latihan mengajar(PUB-Praktikum) mempunyai kesan langsung yang signifikan dengan penguasaan PMUP

H4: Peluang untuk mengikuti program pendidikan guru koheren (PUBProgram) mempunyai kesan langsung yang signifikan dengan PMUP

Melalui tinjauan literatur, pengkaji mendapati kajian oleh Philippou dan Christou (2002) telah menunjukkan KEPM telah memberikan kesan terhadap KEPM guru sekolah rendah. Beberapa hipotesis telah dibina untuk menguji pengaruh faktor PUB terhadap KEPM guru berdasarkan kajian lepas.

H5: Peluang untuk menjalani latihan mengajar (PUB-Praktikum) mempunyai kesan langsung yang signifikan dengan KEPMP

H6: Peluang untuk mengikuti program pendidikan guru koheren (PUBProgram) mempunyai kesan langsung yang signifikan dengan KEPMP

H7: Peluang untuk menjalani latihan mengajar (PUB-Praktikum) mempunyai kesan langsung yang signifikan dengan KJHPM

H8: Peluang untuk mengikuti program pendidikan guru koheren (PUBProgram) mempunyai kesan langsung yang signifikan dengan KJHPM 


\section{METODOLOGI KAJIAN}

\section{Kaedah Pengumpulan Data}

Kaedah pengumpulan data yang digunakan adalah dengan menjalankan kajian tinjauan menggunakan borang soal selidik ke atas 187 orang guru pra perkhidmatan di IPG. Sebelum menjalankan kajian tinjauan, pengkaji terlebih dahulu telah menyediakan satu set borang soal selidik yang mengandungi maklumat-maklumat yang diperlukan bagi menjawab soalan kajian yang telah dikemukakan. Borang soal selidik tersebut terdiri daripada tiga bahagian. Bahagian pertama mengandungi soalan-soalan berkaitan maklumat demografi, bahagian kedua pula mengandungi soalan berkaitan kepercayaan efikasi guru dan bahagian terakhir terdiri daripada maklumat berkaitan PUB. Selain daripada itu, pengkaji juga menggunakan ujian pensel dan kertas bagi mendapatkan data berkaitan tahap PMUP. Kaedah pensampelan rawak berkelompok telah digunakan bagi memilih responden kajian. Sampel yang terlibat adalah guru pra perkhidmatan yang telah selesai menjalani praktikum Fasa 1, iaitu yang sedang mengikuti pengajian di semester 6 hingga 8.

\section{Instrumen Kajian}

Soal selidik yang digunakan diadaptasi daripada kajian lepas yang relevan dengan kajian ini. Oleh kerana instrumen yang digunakan telah memenuhi aspek kesahan dan kebolehpercayaan, maka aspek kesahan kandungan telah dipenuhi (SanchezFranco \& Roldán, 2010). Selain itu, pengkaji juga telah merujuk kepada beberapa orang pakar bagi memastikan instrumen yang digunakan adalah sah dari segi kandungannya. Nilai indeks kesahan kandungan (I-CVI) menunjukkan kesemua item adalah sah kerana nilainya melebihi 0.70 (Polit \& Beck, 2006). Pembentukan alat kajian untuk mengukur pemboleh ubah PMUP diadaptasi daripada Hill, Schilling dan Ball (2004). Item-item bagi mengukur PMUP guru pra perkhidmatan terdiri daripada 15 item berkaitan PK matematik dan 17 item yang menguji PPK matematik . Bagi item yang menguji PK matematik, 4 item terdiri daripada domain pengetahuan kandungan bersama dan 11 item daripada domain pengetahuan kandungan khusus. Manakala bagi item yang menguji PPK matematik pula, 13 item terdiri daripada domain pengetahuan berkaitan kandungan dan pelajar dan 4 item lagi daripada domain pengetahuan berkaitan kandungan dan pengajaran.

Instrumen bagi mengukur pemboleh ubah KEPM telah diadaptasi daripada Enochs, Smith dan Huinker (2000). Instrumen tersebut terdiri daripada dua dimensi, iaitu KEPMP dan KJHPM. Instrumen tersebut mengandungi 21 item secara keseluruhan, iaitu 13 item berkaitan KEPMP dan 8 item berkaitan KJHPM. 
Sementara itu, konstruk-konstruk yang mengukur PUB pula diadaptasi daripada Tatto et al. (2008). Item-item tersebut merupakan sebahagian daripada item yang digunakan dalam kajian TEDS-M oleh International Association for the Evaluation of Educational Achievement (IEA). Ia mengandungi lapan item yang mengukur PUB-Praktikum dan enam item yang mengukur PUBProgram.

\section{ANALISIS DATA}

Perisian Program Pakej Statistik untuk Sains Sosial (SPSS) versi 23 digunakan untuk analisis deskriptif. Analisis deskriptif digunakan untuk mendapatkan maklumat seperti nilai min, peratusan, sisihan piawai, ujian kenormalan, analisis kehilangan data dan ujian andaian multivariat. Ujian kenormalan, analisis kehilangan data dan ujian andaian multivariat adalah penting untuk dilaksanakan sebelum analisis pengujian hipotesis dijalankan.

Perisian SmartPLS 3.0 digunakan untuk menganalisis data bagi menguji hipotesis kajian. Dua prosedur analisis data digunakan dalam kajian ini seperti yang disarankan oleh Hair, Hult, Ringle dan Sarstedt (2017), iaitu penilaian model pengukuran dan penilaian model struktural.

\section{Model Pengukuran}

Menurut Hair et al. (2017), pengujian hipotesis akan hanya dijalankan sekiranya model pengukurannya mencapai tahap kebolehpercayaan dan kesahan yang diingini. Bagi menilai kebolehpercayaan bagi setiap pemboleh ubah kajian, nilai alfa Cronbach dan Composite Reliability telah digunakan. Berdasarkan analisis yang telah dijalankan didapati nilai alfa Cronbach bagi setiap konstruk melebihi 0.7, iaitu merupakan tahap paling minimum (Nunnally \& Bernstein, 1994). Selain itu, pengkaji juga turut merujuk kepada nilai Composite Reliability bagi menentukan kebolehpercayaan setiap konstruk. Berdasarkan analisis yang telah dijalankan didapati nilai Composite Reliability bagi semua konstruk adalah melebihi 0.7, maka ianya boleh diterima.

Pengujian kesahan konstruk pula dijalankan melalui penilaian aspek Kesahan Menumpu (Convergent Validity) dan Kesahan Pembeza (Discriminant Validity). Sesuatu pemboleh ubah dianggap mempunyai kesahan menumpu sekiranya tiga kriteria dipenuhi, pertama, nilai factor loading semua item individu mesti melebihi 0.708. Namun begitu, item yang mempunyai nilai factor loading di antara 0.4 hingga 0.7 adalah boleh dipertimbangkan untuk dikekalkan (Hair et al., 2017). 
Berdasarkan dapatan kajian dalam Jadual 1, didapati terdapat beberapa item yang mempunyai nilai factor loading yang kurang daripada 0.708 tetapi itemitem tersebut dikekalkan kerana dengan membuang item berkenaan (bertulisan tebal) ianya tidak meningkatkan nilai AVE dan kebolehpercayaan komposit bagi konstruk berkenaan (Hair et al., 2017). Kedua, nilai kebolehpercayaan komposit tidak kurang daripada 0.6 dan yang ketiga nilai AVE mestilah melebihi 0.5 (Fornell \& Larcker, 1981).

Jadual 1. Keputusan analisis model pengukuran

\begin{tabular}{|c|c|c|c|c|c|}
\hline \multirow[b]{2}{*}{ Konstruk } & \multirow[b]{2}{*}{ Item } & \multirow[b]{2}{*}{$\begin{array}{l}\text { Kebolehpercayaan } \\
\text { dalaman } \\
\text { (Cronbach's alpha) }\end{array}$} & \multicolumn{3}{|c|}{ Kesahan menumpu } \\
\hline & & & $\begin{array}{l}\text { Factor } \\
\text { loading }\end{array}$ & $\begin{array}{l}\text { Composite } \\
\text { reliability }\end{array}$ & $\begin{array}{l}\text { Average } \\
\text { Variance } \\
\text { Extracted }\end{array}$ \\
\hline \multirow[t]{8}{*}{ PUB-Praktikum } & PUB_Prak1 & 0.916 & 0.801 & 0.932 & 0.631 \\
\hline & PUB_Prak2 & & 0.830 & & \\
\hline & PUB_Prak3 & & 0.863 & & \\
\hline & PUB_Prak4 & & 0.808 & & \\
\hline & PUB_Prak5 & & 0.770 & & \\
\hline & PUB_Prak6 & & 0.780 & & \\
\hline & PUB_Prak7 & & 0.741 & & \\
\hline & PUB_Prak8 & & 0.752 & & \\
\hline \multirow[t]{6}{*}{ PUB-Program } & PUB_Prog1 & 0.896 & 0.790 & 0.921 & 0.660 \\
\hline & PUB _Prog2 & & 0.730 & & \\
\hline & PUB_Prog3 & & 0.870 & & \\
\hline & PUB_Prog4 & & 0.815 & & \\
\hline & PUB_Prog5 & & 0.823 & & \\
\hline & PUB_Prog6 & & 0.840 & & \\
\hline
\end{tabular}


Jadual 1. (sambungan)

\begin{tabular}{|c|c|c|c|c|c|}
\hline \multirow[b]{2}{*}{ Konstruk } & \multirow[b]{2}{*}{ Item } & \multirow[b]{2}{*}{$\begin{array}{l}\text { Kebolehpercayaan } \\
\text { dalaman } \\
\text { (Cronbach's alpha) }\end{array}$} & \multicolumn{3}{|c|}{ Kesahan menumpu } \\
\hline & & & $\begin{array}{l}\text { Factor } \\
\text { loading }\end{array}$ & $\begin{array}{l}\text { Composite } \\
\text { reliability }\end{array}$ & $\begin{array}{l}\text { Average } \\
\text { Variance } \\
\text { Extracted }\end{array}$ \\
\hline \multirow[t]{10}{*}{ КEPMP } & KEPMP1 & 0.891 & 0.781 & 0.911 & 0.510 \\
\hline & KEPMP2 & & 0.741 & & \\
\hline & KEPMP3 & & 0.672 & & \\
\hline & KEPMP4 & & 0.697 & & \\
\hline & KEPMP5 & & 0.873 & & \\
\hline & KEPMP6 & & 0.635 & & \\
\hline & KEPMP7 & & 0.728 & & \\
\hline & KEPMP10 & & 0.606 & & \\
\hline & KEPMP11 & & 0.746 & & \\
\hline & KEPMP12 & & 0.741 & & \\
\hline \multirow[t]{8}{*}{ KJHPM } & KJHPM1 & 0.896 & 0.684 & 0.916 & 0.580 \\
\hline & KJHPM2 & & 0.685 & & \\
\hline & КJHРM3 & & 0.766 & & \\
\hline & KJHPM4 & & 0.790 & & \\
\hline & KJHPM5 & & 0.770 & & \\
\hline & KJHPM6 & & 0.880 & & \\
\hline & KJHPM7 & & 0.726 & & \\
\hline & КJHРM8 & & 0.771 & & \\
\hline PMUP & & $\mathrm{NA}^{*}$ & & $\mathrm{NA}^{*}$ & $\mathrm{NA}^{*}$ \\
\hline
\end{tabular}

Nota: * Pengukuran item tunggal

Manakala kesahan pembeza pula dipenuhi sekiranya nilai punca kuasa AVE adalah melebihi nilai korelasi pemboleh ubah pendam (Fornell \& Larcker, 1981). Di samping itu, kesahan pembeza juga boleh dinilai melalui pengujian nilai silang (cross loading) item kajian (Hair et al., 2017). Sebagaimana yang ditunjukkan dalam Jadual 2, nilai punca kuasa AVE pemboleh ubah kajian ini adalah melebihi nilai korelasi pemboleh ubah pendam. Oleh yang demikian, data kajian rintis menunjukkan setiap pemboleh ubah kajian memenuhi kriteria yang diperlukan. 
Jadual 2. Analisis kesahan pembeza konstruk kajian

\begin{tabular}{lccccc}
\hline Konstruk & $(1)$ & $(2)$ & $(3)$ & $(4)$ & (5) \\
\hline (1) KEPMP & 0.714 & & & & \\
(2) KJHPM & 0.203 & $\mathbf{0 . 7 6 1}$ & & & \\
(3) PUB-Praktikum & 0.399 & 0.074 & $\mathbf{0 . 7 9 4}$ & & \\
(4) PUB-Program & 0.389 & 0.119 & 0.467 & $\mathbf{0 . 8 1 3}$ & \\
(5) PMUP & 0.366 & 0.393 & 0.577 & 0.553 & $*$ N/A \\
\hline
\end{tabular}

Nota $:$ PMUP = Pengetahuan Matematik untuk Pengajaran; KEPMP = Kepercayaan Efikasi Peribadi Pengajaran Matematik; KJHPM = Kepercayaan Jangkaan Hasil Pengajaran Matematik; PUB-Program = Peluang Untuk Belajar Program Pendidikan Guru Koheren; PUB-Praktikum = Peluang Untuk Belajar Latihan Mengajar

\section{Model Struktural dan Pengujian Hipotesis}

Model struktural menjelaskan hubungan antara satu pemboleh ubah pendam dengan pemboleh ubah pendam yang lain (Hair et al., 2017). Analisis model struktural bukan hanya bertujuan untuk menguji hipotesis, tetapi ia juga melibatkan pengujian kekuatan hubungan di antara pemboleh ubah bersandar dan pemboleh ubah bebas. Selain itu, model struktural juga memaparkan jumlah varian $\left(\mathrm{R}^{2}\right)$ yang dijelaskan oleh pemboleh ubah bebas ke atas pemboleh ubah bersandar dan keseluruhan model. Jadual 3 dan Rajah 2 menunjukkan dapatan daripada analisis yang telah dijalankan.

Dapatan daripada analisis ke atas model struktural sebagaimana yang dilampirkan (rujuk Appendix) menunjukkan, (H1) KEPMP tidak mempunyai kesan langsung yang signifikan terhadap pengetahuan matematik untuk pengajaran $(\beta=0.017, p>0.1)$, (H2) KJHPM mempunyai kesan langsung yang signifikan terhadap pengetahuan matematik untuk pengajaran $(\beta=0.322$, $p<0.001$ ), (H3) PUB-Praktikum mempunyai kesan langsung yang signifikan terhadap pengetahuan matematik untuk pengajaran $(\beta=0.395, p<0.001)$, (H4) PUB-Program mempunyai kesan langsung yang signifikan terhadap pengetahuan matematik untuk pengajaran $(\beta=0.325, p<0.001)$. Selain itu, dapatan daripada analisis yang telah dijalankan juga mendapati faktor (H5) PUB-Praktikum mempunyai kesan langsung yang signifikan terhadap KEPMP $(\beta=0.277$, $p<0.001$ ) dan (H6) PUB-Program juga mempunyai kesan langsung yang signifikan terhadap KEPMP $(\beta=0.260, p<0.001)$. Manakala pengaruh faktor $(\mathrm{H} 7)$ PUB-Praktikum dan (H8) PUB-Program pula didapati tidak mempunyai kesan langsung yang signifikan terhadap KJHPM $(\beta=0.024, p>0.1$ dan $\beta=0.10$, $p>0.1$ ). Secara keseluruhan, model tersebut menjelaskan nilai varian terhadap 
faktor-faktor mempengaruhi pengetahuan matematik untuk pengajaran adalah sebanyak 54\% (Jadual 4).

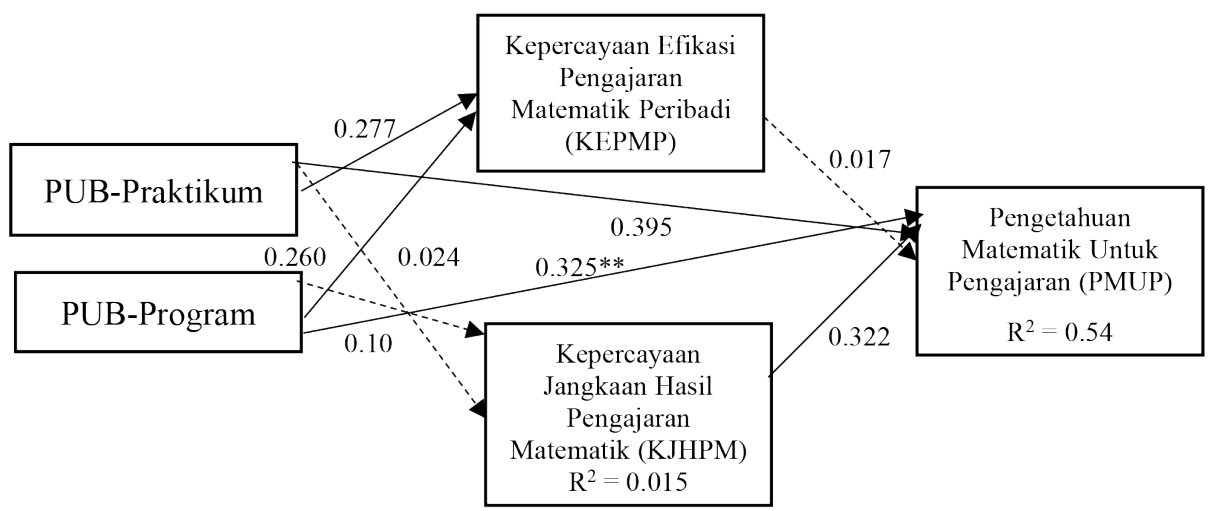

Rajah 2. Model struktural

Jadual 3. Ringkasan pengujian hipotesis kajian

\begin{tabular}{lccc}
\hline Hipotesis & $\beta$ & Nilai- $t$ & Keputusan \\
\hline (H1) KEPMP $\rightarrow$ PMUP & 0.017 & 0.284 & Tidak \\
$($ H2) KJHPM $\rightarrow$ PMUP & $0.322^{*}$ & 5.669 & Ya \\
$($ H3) PUB-Praktikum $\rightarrow$ PMUP & $0.395^{*}$ & 6.853 & Ya \\
$($ H4) PUB-Program $\rightarrow$ PMUP & $0.324^{*}$ & 5.179 & Ya \\
$($ H5) PUB-Praktikum $\rightarrow$ KEPMP & $0.277^{*}$ & 3.745 & Ya \\
$($ H6) PUB-Program $\rightarrow$ KEPMP & 0.260 & 3.256 & Ya \\
$($ H7) PUB-Praktikum $\rightarrow$ KJHPM & 0.024 & 0.281 & Tidak \\
$($ H8) PUB-Program $\rightarrow$ KJHPM & 0.108 & 1.244 & Tidak \\
\hline
\end{tabular}

Nota: *nilai $p<0.001$

Jadual 4. Nilai $\mathrm{R}^{2}$ model kajian

\begin{tabular}{lc}
\hline Konstruk & $\mathrm{R}^{2}$ \\
\hline Pengetahuan matematik untuk pengajaran (PMUP) & 0.54 \\
Kepercayaan efikasi pengajaran matematik peribadi (KEPMP) & 0.212 \\
Kepercayaan jangkaan hasil pengajaran matematik (KJHPM) & 0.015 \\
\hline
\end{tabular}




\section{PERBINCANGAN}

Kajian ini dijalankan untuk mengkaji faktor-faktor yang mempengaruhi PMUP dalam kalangan guru pra perkhidmatan di Malaysia. Kajian ini telah menguji pengaruh faktor KEPM dan PUB terhadap PMUP dan pengaruh faktor PUB terhadap KEPM guru.

Berdasarkan analisis yang dijalankan, didapati faktor KJHPM mempunyai hubungan yang signifikan dengan PMUP $(\beta=0.322, p<0.001)$. Dapatan ini mengesahkan bahawa guru pra perkhidmatan yang mempunyai KJHPM positif yang tinggi akan turut menguasai PMUP yang dipelajari semasa mengikuti program pendidikan guru di IPG. Dapatan ini mengesahkan bahawa guru pra perkhidmatan yang mempunyai KEPM yang tinggi akan turut menguasai PMUP yang dipelajari semasa mengikuti program pendidikan guru di IPG.

Terdapat beberapa kemungkinan yang menyebabkan faktor KJHPM berperanan mempengaruhi tahap penguasaan PMUP guru pra perkhidmatan. Antaranya adalah kerana mereka mempercayai bahawa kaedah pengajaran yang efektif dapat mempengaruhi pencapaian matematik pelajar (Blazar, 2015). Keyakinan guru pra perkhidmatan berkaitan kepentingan pengajaran yang berkesan mungkin telah sedikit sebanyak mempengaruhi PMUP mereka. Ini adalah kerana menurut Blazar (2015), aktiviti pengajaran yang berkesan mampu mempengaruhi pencapaian pelajar. Sebagai contoh, sekiranya seseorang guru percaya bahawa pengajaran berkesan dapat menyumbang kepada pencapaian matematik pelajar, maka ini akan memberikan galakan kepada mereka untuk mendalami PMUP bagi memastikan mereka dapat mengajar dengan lebih berkesan pada masa akan datang.

Dapatan daripada pengujian hipotesis ini disokong oleh beberapa dapatan daripada kajian terdahulu. Antaranya dapatan daripada kajian oleh Swars et al. (2007; 2009) yang mendapati KJHPM merupakan antara salah satu faktor yang mempengaruhi PMUP guru pra perkhidmatan di Amerika Syarikat. Namun begitu, berbeza bagi dapatan kajian oleh Newton, Evans, Eastburn dan Leonard (2007) menunjukkan faktor KJHPM tidak mempengaruhi PMUP guru.

Sebagai pihak yang bertanggungjawab melatih guru pra perkhidmatan yang akan berkhidmat sebagai guru matematik sekolah rendah, IPGM seharusnya mengambil beberapa langkah yang perlu bagi memastikan tahap KJHPM dapat ditingkatkan. Peningkatan tahap KJHPM adalah penting kerana ianya merupakan salah satu faktor yang menyumbang kepada peningkatan tahap penguasaan PMUP dalam kalangan guru pra perkhidmatan di IPG. Selain daripada faktor PUB yang diperoleh sepanjang mengikuti program pendidikan guru di IPG, faktor lain yang 
dikenal pasti dapat mempengaruhi KJHPM mereka adalah kecerdasan emosi (Alrajhi et al., 2017). Justeru dicadangkan supaya pihak IPGM dapat merangka kurikulum pendidikan matematik yang mampu merangsang kecerdasan emosi guru pra perkhidmatan pada masa akan datang.

Selain itu, menurut Lotter et al. (2016) dan Pape et al. (2015) pula, tahap kepercayaan efikasi guru boleh ditingkatkan melalui program pembangunan profesional. Sepanjang mengikuti program pendidikan guru di IPG, para guru pelatih telah didedahkan dengan pelbagai kursus bagi memastikan mereka mampu menjadi seorang guru yang kompeten pada masa akan datang. Justeru pihak IPGM dicadangkan supaya menggandakan usaha bagi menyediakan kursus-kursus dan program pembangunan profesional yang lebih mantap bagi memastikan tahap kepercayaan efikasi guru pra perkhidmatan dapat ditingkatkan dan secara tidak langsung menyumbang kepada peningkatan dalam penguasaan PMUP mereka.

Dapatan daripada pengujian hipotesis yang telah dijalankan menunjukkan bahawa faktor PUB mempunyai hubungan positif yang paling kuat dengan PMUP guru pra perkhidmatan di IPG. Maklumat lanjut mengenai hasil daripada analisis yang dijalankan telah dipaparkan dalam Jadual 3. Dapatan ini mengesahkan bahawa guru pra perkhidmatan yang memperoleh PUB positif yang tinggi akan turut menguasai PMUP yang dipelajari semasa mengikuti program pendidikan guru di IPG. Berdasarkan analisis yang telah dijalankan juga mendapati faktor PUB dalam kalangan guru pra perkhidmatan dijelaskan oleh faktor peluang untuk menjalani latihan mengajar secara lebih dominan $(\beta=0.395, p<0.001)$ berbanding faktor peluang untuk mengikuti program pendidikan guru koheren $(\beta=0.325, p<0.001)$.

Menurut Gerasimova et al. (2017), keseimbangan di antara teori dan amalan adalah penting bagi melahirkan bakal guru yang berkualiti pada masa akan datang. Setiap guru pra perkhidmatan di IPG telah diberikan peluang yang secukupnya untuk mendalami ilmu sama ada dari segi teori dan amalan. Kurikulum yang dirangka oleh pihak IPGM mencakupi semua aspek bagi memastikan bakal guru yang dihasilkan mampu untuk bersaing dan dapat mendidik pelajar dengan jayanya.

Selain itu, peluang menjalani latihan mengajar (praktikum) sebanyak dua fasa, iaitu kira-kira selama tiga bulan bagi setiap fasa dengan dibimbing oleh pensyarah dan guru pembimbing yang berpengalaman juga sedikit sebanyak menyumbang kepada persepsi guru pra perkhidmatan berkaitan PUB yang diperoleh sepanjang mengikuti program pendidikan guru di IPG. Ini adalah kerana menurut Toh, Berinderjeet dan Koay (2009), tempoh menjalani latihan mengajar yang mencukupi dapat mempengaruhi tahap penguasaan PMUP guru pra perkhidmatan. Dapatan ini mengesahkan bahawa guru pra perkhidmatan yang 
memperoleh PUB positif yang tinggi akan turut menguasai PMUP yang dipelajari semasa mengikuti program pendidikan guru di IPG.

Dapatan ini disokong oleh beberapa dapatan daripada kajian terdahulu. Kajian oleh Adamson (2012) mendapati PUB merupakan salah satu faktor yang mempengaruhi PMUP guru pra perkhidmatan. Kajian oleh Ayieko (2014) turut mendapati faktor PUB telah mempengaruhi pengetahuan guru. Selain itu, kajian yang dijalankan oleh Livy, Vale dan Herbert (2016) ke atas dua orang guru pra perkhidmatan di Australia turut mendapati pengalaman praktikum adalah faktor penting yang dapat membantu mereka membentuk PK matematik.

Dapatan daripada kajian oleh Tatto et al. (2015) menunjukkan bahawa terdapat hubungan yang signifikan antara PUB yang diperoleh oleh guru perkhidmatan semasa mengikuti program pendidikan guru dengan PMUP. Kajian tersebut telah dijalankan ke atas guru pra perkhidmatan di beberapa buah negara dengan menggunakan data daripada IEA. Sementara itu, kajian oleh Qian dan Youngs (2016) pula telah dijalankan ke atas guru-guru di lima buah negara dengan menggunakan data TEDS-M turut mendapati faktor PUB mempengaruhi penguasaan pengetahuan seseorang guru pra perkhidmatan.

Dapatan daripada kajian-kajian lain juga turut menyokong dapatan kajian ini, antaranya kajian oleh Blömeke, Jenßen, Grassmann, Dunekacke dan Wedekind (2016), Blömeke, Suhl, Kaiser dan Döhrmann (2012), dan Konig et al. (2017). Dapatan daripada kajian yang dijalankan oleh Blömeke et al. (2012) dan Blömeke et al. (2012, 2016) menunjukkan terdapat hubungan yang signifikan di antara PUB dengan PMUP guru pra perkhidmatan. Kajian tersebut dijalankan ke atas pra perkhidmatan di Jerman. Sementara itu, kajian oleh Konig et al. (2017) pula telah dijalankan ke atas 444 orang Jerman, turut mendapati faktor PUB mempengaruhi penguasaan pengetahuan guru pra perkhidmatan.

Kajian terkini yang dijalankan oleh Livy dan Downton (2018) bagi guru-guru di Australia turut mendapati faktor PUB mempengaruhi PMUP guru. Selain itu, kajian oleh Murray, Durkin, Chao dan Star (2018) juga menunjukkan terdapat hubungan yang signifikan antara PUB dengan PMUP.

Peranan IPGM sebagai sebuah institusi yang bertanggungjawab untuk melahirkan guru matematik yang kompeten, adalah tanda pihak KPM untuk menyediakan peruntukan yang mencukupi bagi memastikan PUB yang seluas-luasnya dapat dinikmati oleh guru pra perkhidmatan. Selain daripada memberi peluang untuk menjalani praktikum dan program pendidikan guru yang koheren, guru pra perkhidmatan juga seharusnya diberikan peluang untuk mempelajari ilmu 
berkaitan pedagogi secara lebih berkesan. Ini adalah kerana menurut Blömeke et al. (2016), faktor peluang untuk mempelajari ilmu berkaitan pedagogi umum dan pedagogi matematik dapat mempengaruhi tahap penguasaan pengetahuan guru pra perkhidmatan. Penyampaian ilmu berkaitan pedagogi kepada para guru pra perkhidmatan adalah berkait secara langsung dengan struktur kurikulum dan kualiti pensyarah. Justeru bagi menjamin penyampaian ilmu berkaitan pedagogi yang lebih berkesan, dicadangkan supaya pihak IPGM sentiasa mengemas kini kurikulum pendidikan matematik dan pada masa yang sama turut menjalankan usaha berterusan bagi meningkatkan kompetensi para pensyarah matematik dalam penyampaian ilmu berkaitan pedagogi (pendidikan matematik).

Dapatan daripada pengujian H5 dan H6 menunjukkan bahawa faktor PUB mempunyai hubungan yang positif dengan KEPM. Maklumat lanjut hasil daripada analisis yang dijalankan telah dipaparkan dalam Jadual 3. Dapatan ini mengesahkan bahawa guru pra perkhidmatan yang memperoleh PUB positif yang tinggi akan turut mempengaruhi KEPM mereka.

Keadaan ini mungkin berlaku disebabkan oleh pengalaman yang dilalui oleh guru pra perkhidmatan sepanjang mengikuti program pendidikan guru telah mempengaruhi kepercayaan efikasi kendiri mereka. Sebagai contoh, pengalaman menjalani program pengalaman berasaskan sekolah, latihan pengajaran mikro dan pengalaman praktikum telah menyebabkan mereka percaya bahawa pembelajaran pelajar adalah dipengaruhi oleh pengajaran yang berkesan (KJHPM). Selain itu, pengalaman yang dilalui sepanjang mengikuti program pendidikan guru juga berkemungkinan telah menyebabkan mereka berasa lebih yakin berkaitan keupayaan mereka untuk mengajar (KEPMP).

Dapatan ini disokong oleh beberapa dapatan daripada kajian terdahulu. Antaranya dapatan daripada kajian oleh Swars et al. (2007; 2009) yang mendapati, PUB merupakan salah satu faktor yang mempengaruhi KEPM guru pra perkhidmatan. Dapatan daripada kajian-kajian lain juga turut menyokong dapatan kajian ini, antaranya kajian oleh Philippou dan Christou (2002) yang turut mendapati faktor peluang untuk mengikuti program pendidikan guru yang koheren mempengaruhi KEPM guru. Kajian terkini yang dijalankan oleh Berger, Girardet, Vaudroz dan Crahay (2018) ke atas 154 orang guru vokasional turut mendapati faktor pengalaman mengajar (PUB-Praktikum) mempengaruhi kepercayaan efikasi guru. 


\section{BATASAN DAN CADANGAN PENYELIDIKAN AKAN DATANG}

Kajian berkaitan pengetahuan guru merupakan satu bidang kajian yang berterusan dan sedang berkembang. Berdasarkan analisis kritikal yang telah dijalankan, didapati sepanjang tahun 2017 sehingga bulan Jun 2018, sudah terdapat hampir 30 kajian berkaitan pengetahuan guru yang diterbitkan dalam jurnal-jurnal terpilih. Ini jelas membuktikan bahawa kajian berkaitan pengetahuan guru adalah penting dan menjadi tumpuan para pengkaji di seluruh dunia. Menurut Ren et al. (2017), lebih banyak kajian diperlukan pada masa akan datang bagi menjelaskan bagaimana pengetahuan matematik dan kepercayaan guru adalah saling berkaitan di antara satu sama lain.

Kajian ini hanya memfokuskan faktor-faktor yang mempengaruhi PMUP dalam kalangan guru pra perkhidmatan sahaja. Justeru pada masa akan datang dicadangkan supaya skop kajian diperluaskan kepada guru-guru matematik dalam perkhidmatan dan pensyarah matematik di IPG dan Institusi Pengajian Tinggi Awam. Selain itu, turut dicadangkan pada masa akan datang supaya kajian ini diperluaskan kepada guru-guru pra perkhidmatan dalam bidang pendidikan awal kanak-kanak dan pemulihan. Hal ini adalah kerana kedua-dua bidang tersebut turut memerlukan penguasaan PMUP dalam melaksanakan pengajaran mereka.

Selain itu, dari sudut pengujian model pula, dicadangkan pada masa akan datang pengujian faktor-faktor seperti status sosio ekonomi dan penglibatan dalam pengajaran dan penyelidikan (teaching and research) sebagai pemboleh ubah yang mempengaruhi PMUP. Ini adalah kerana menurut Tatto et al. (2015), faktor status sosio ekonomi turut mempengaruhi penguasaan PK dan PPK guru pra perkhidmatan. Sementara itu, kajian oleh Mu, Liang, Lu dan Huang (2018) pula mendapati, faktor penglibatan dalam pengajaran dan penyelidikan turut mempengaruhi pengetahuan guru. Justeru, pada masa akan datang dicadangkan kedua-dua faktor tersebut dimasukkan dan diuji dalam model faktor-faktor yang mempengaruhi PMUP guru pra perkhidmatan.

\section{KESIMPULAN}

Dapatan daripada kajian ini mendedahkan bahawa faktor utama yang mempengaruhi PMUP guru pra perkhidmatan adalah PUB. Penyediaan peluang untuk mengikuti program pendidikan guru yang koheren serta peluang untuk menjalani latihan mengajar oleh pihak IPG didapati telah mempengaruhi PMUP mereka secara positif. Justeru pada masa akan datang, dicadangkan supaya pihak IPG menyediakan peluang-PUB yang lebih kepada guru pra perkhidmatan bagi 
membantu mereka meningkatkan penguasaan PMUP. Menurut Barnard-Brak, Lan dan Yang (2018) dan Irvin, Byun, Smiley dan Hutchins (2017), selain daripada mampu meningkat PMUP, faktor PUB juga dapat meningkatkan pencapaian matematik guru pra perkhidmatan.

Selain daripada faktor PUB, faktor KJHPM juga didapati turut mempengaruhi PMUP guru pra perkhidmatan. Secara keseluruhannya, didapati model faktor yang mempengaruhi PMUP guru pra perkhidmatan yang dihasilkan ini adalah sah. Berdasarkan analisis yang dijalankan, didapati kedua-dua faktor, iaitu KEPM dan PUB telah menyumbang sebanyak 54\% varians terhadap PMUP. Ini bermaksud, secara keseluruhannya model ini mempunyai kekuatan peramalan yang sederhana. Justeru terdapat keperluan untuk menjalankan kajian lanjutan pada masa akan datang dengan mengambil kira faktor-faktor yang telah dicadangkan bagi meningkatkan kekuatan peramalan model ini.

\section{RUJUKAN}

Adamson, B. (2012). International comparative studies in teaching and teacher education. Teaching and Teacher Education, 28(5), 641-648. https://doi.org/10.1016/j .tate.2012.02.003

Akkoç, H., \& Yesildere, S. (2010). Investigating development of pre-service elementary mathematics teachers' pedagogical content knowledge through a school practicum course. Procedia - Social and Behavioral Sciences, 2(2), 1410-1415. https://doi .org/DOI: $10.1016 /$ j.sbspro.2010.03.210

Alrajhi, M., Aldhafri, S., Alkharusi, H., Albusaidi, S., Alkharusi, B., Ambusaidi, A., \& Alhosni, K. (2017). The predictive effects of math teachers' emotional intelligence on their perceived self-efficacy beliefs. Teaching and Teacher Education, 67, 378-388. https://doi.org/10.1016/j.tate.2017.07.003

Austin, J. (2015). Prospective teachers' personal mathematics teacher efficacy beliefs and mathematical knowledge for teaching. Mathematics Education, 10(1), 17-36. https://doi.org/10.12973/mathedu.2015.102a

Ayieko R. A. (2014). The influence of opportunity to learn to teach mathematics on pre-service teachers' knowledge and belief: A comparative study. Unpublished doctoral dissertation, Michigan State University.

Ball, D. L., Thames, M. H., \& Phelps, G. (2008). Content knowledge for teaching: What makes it special? Journal of Teacher Education, 59(5), 389-407. https://doi .org/10.1177/0022487108324554

Bandura, A. (1989a). Human agency in social cognitive theory. The American Psychologist, 44(9), 1175-1184. https://doi.org/10.1037/0003-066x.44.9.1175

Bandura, A. (1989b). Social cognitive theory. Annals of Child Development, 6, 1-6. 
Barnard-Brak, L., Lan, W. Y., \& Yang, Z. (2018). Differences in mathematics achievement according to opportunity to learn: A 4pL item response theory examination. Studies in Educational Evaluation, 56(August 2017), 1-7. https://doi.org/10.1016/j .stueduc.2017.11.002

Berger, J. L., Girardet, C., Vaudroz, C., \& Crahay, M. (2018). Teaching experience, teachers' beliefs, and self-reported classroom management practices: A coherent network. SAGE Open, 8(1), 1-12. https://doi.org/10.1177/2158244017754119

Blazar, D. (2015). Effective teaching in elementary mathematics: Identifying classroom practices that support student achievement. Economics of Education Review, 48, 16-29. https://doi.org/10.1016/j.econedurev.2015.05.005

Blömeke, S., Jenßen, L., Grassmann, M., Dunekacke, S., \& Wedekind, H. (2016). Process mediates structure: The relation between preschool teacher education and preschool teachers' knowledge. Journal of Educational Psychology, 109(3), 338354. https://doi.org/10.1037/edu0000147

Blömeke, S., Suhl, U., Kaiser, G., \& Döhrmann, M. (2012). Family background, entry selectivity and opportunities to learn: What matters in primary teacher education? An international comparison of fifteen countries. Teaching and Teacher Education, 28(1), 44-55. https://doi.org/10.1016/j.tate.2011.08.006

Buchholtz, N. F. (2017). The acquisition of mathematics pedagogical content knowledge in university mathematics education courses: Results of a mixed methods study on the effectiveness of teacher education in Germany. ZDM - Mathematics Education, 49(2), 249-264. https://doi.org/10.1007/s11858-017-0849-5

Dunekacke, S., Jenben, L., Eilerts, K., \& Blomeke, S. (2016). Epistemological beliefs of prospective preschool teachers and their relation to knowledge, perception, and planning abilities in the field of mathematics: A process model. ZDM Mathematics Education, 48(1-2), 125-137. https://doi.org/10.1007/s11858-0150711-6

Ekstam, U., Korhonen, J., Linnanmäki, K., \& Aunio, P. (2017). Special education preservice teachers' interest, subject knowledge, and teacher efficacy beliefs in mathematics. Teaching and Teacher Education, 63, 338-345. https://doi .org/10.1016/j.tate.2017.01.009

Enochs, L. G., Smith, P. L., \& Huinker, D. (2000). Establishing factorial validity of the mathematics teaching efficacy beliefs instrument. School Science and Mathematics, 100(4), 194-202.

Fornell, C., \& Larcker, D. F. (1981). Evaluating structural equation models with unobservable variables and measurement error. Journal of Marketing Research, 18(1), 39-50. https://doi.org/10.2307/3151312

Gerasimova, E., Shcherbatykh, S., Savvina, O., Simonovskaya, G., Masina, O., Trofimova, E., \& Tarasova, O. (2017). Coexistence of theory and practice in training the future mathematics teacher: The experience of the Russian education system. Eurasia Journal of Mathematics, Science and Technology Education, 8223(12), 7695-7705. https://doi.org/10.12973/ejmste/80359

Goos, M. (2013). Knowledge for teaching secondary school mathematics: What counts? International Journal of Mathematical Education in Science and Technology, 44(7), 972-983. https://doi.org/10.1080/0020739X.2013.826387 
Hair, J. F. J., Hult, G. T. M., Ringle, C. M., \& Sarstedt, M. (2017). A primer on Partial Least Squares Structural Equation Modeling (PLS-SEM). SAGE Publications Ltd.

Hill, H. C., Schilling, S. G., \& Ball, D. L. (2004). Developing measures of teachers' mathematics knowledge for teaching. The Elementary School Journal, 105(1), $11-30$.

Hine, G. S. C. (2015). Strengthening pre-service teachers' mathematical content knowledge. Teaching and Learning Forum, 12(4), 1-11.

Irvin, M., Byun, S., Smiley, W. S., \& Hutchins, B. C. (2017). Relation of opportunity to learn advanced math to the educational attainment of rural youth. American Journal of Education, 123(3), 475-510. https://doi.org/10.1086/691231

Kementerian Kewangan Malaysia. (2017). Bajet 2017. Putrajaya: Author.

Kleickmann, T., Richter, D., Kunter, M., Elsner, J., Besser, M., Krauss, S., \& Baumert, J. (2013). Teachers' content knowledge and pedagogical content knowledge: The role of structural differences in teacher education. Journal of Teacher Education, 64(1), 90-106. https://doi.org/10.1177/0022487112460398

Kleickmann, T., Richter, D., Kunter, M., Elsner, J., Besser, M., Krauss, S., Cheo, M., \& Baumert, J. (2015). Content knowledge and pedagogical content knowledge in Taiwanese and German mathematics teachers. Teaching and Teacher Education, 46, 115-126. https://doi.org/10.1016/j.tate.2014.11.004

Konig, J., Tachtsoglou, S., Lammerding, S., Straub, S., Nold, G., \& Rohde, A. (2017). The role of opportunities to learn in teacher preparation for EFL teachers' pedagogical content knowledge. The Modern Language Journal, 101(1), 1-19. https://doi .org/10.1111/modl.12383

Leong K. E., Chew C. M, \& Abdul Rahim S. S. (2015). Understanding Malaysian preservice teachers mathematical content knowledge and pedagogical content knowledge. Eurasia Journal of Mathematics, Science and Technology Education, 11(2), 363-370. https://doi.org/10.12973/eurasia.2015.1346a

Livy, S., \& Downton, A. (2018). Exploring experiences for assisting primary pre-service teachers to extend their knowledge of student strategies and reasoning. Journal of Mathematical Behavior, 51(September), 1-11. https://doi.org/10.1016/j .jmathb.2017.11.004

Livy, S., Vale, C., \& Herbert, S. (2016). Developing primary pre-service teachers' mathematical content knowledge during practicum teaching. Australian Journal of Teacher Education, 41(2), 152-173. https://doi.org/10.14221/ajte.2016v41n2.10

Lotter, C. R., Thompson, S., Dickenson, T. S., Smiley, W. F., Blue, G., \& Rea, M. (2016). The impact of a practice-teaching professional development model on teachers' inquiry instruction and inquiry efficacy beliefs. International Journal of Science and Mathematics Education, 16(2), 255-273. https://doi.org/10.1007/s10763016-9779-x 
Mohd Tajudin, N., Chinnapan, M., \& Saad, N. S. (2017). Relationship between mathematics teacher subject matter knowledge, pedagogical content knowledge and professional development needs. Proceedings of the International Conference on Education, Mathematics and Science 2016 (ICEMS2016) in Conjunction with 4th International Postgraduate Conference on Science and Mathematics 2016 (IPCSM2016) 1847(1), 030001. https://doi.org/10.1063/1.4983878

Mohd Yusof, Y., \& Zakaria, E. (2010). Investigating secondary mathematics teachers' pedagogical content knowledge: A case study. Journal of Education and Sociology, March, 32-39.

Mosvold, R., \& Fauskanger, J. (2014). Teachers' beliefs about mathematical horizon content knowledge. International Journal of Mathematics Teaching and Learning, September, 1-9.

Mu, G. M., Liang, W., Lu, L., \& Huang, D. (2018). Building pedagogical content knowledge within professional learning communities: An approach to counteracting regional education inequality. Teaching and Teacher Education, 73, 24-34. https://doi .org/10.1016/j.tate.2018.03.006

Murray, E., Durkin, K., Chao, T., \& Star, J. R. (2018). Exploring connections between content knowledge, pedagogical content knowledge, and the opportunities to learn mathematics: Findings from the TEDS-M dataset. Mathematics Teacher Education and Development, 20(March), 4-22.

Newton, K. J., Evans, B. R., Eastburn, J. A, \& Leonard, J. (2007). Preservice elementary teachers' mathematics content knowledge and teacher efficacy. School Science and Mathematics, 112(5), 289-299.

Norton, S. J. (2017). Primary mathematics trainee teacher confidence and its relationship to mathematical knowledge. Australian Journal of Teacher Education, 42(2), 47-61.

Nunnally, J. C., \& Bernstein, I. H. (1994). Psychometric theory (Vol. 3). Mc Graw Hill Inc.

Oppermann, E., Anders, Y., \& Hachfeld, A. (2016). The influence of preschool teachers' content knowledge and mathematical ability beliefs on their sensitivity to mathematics in children's play. Teaching and Teacher Education, 58, 174-184. https://doi.org/10.1016/j.tate.2016.05.004

Pape, S. J., Prosser, S. K., Griffin, C. C., Fichtman Dana, N., Algina, J., \& Bae, J. (2015). Prime online: Developing grades 3-5 teachers' content knowledge for teaching mathematics in an online professional development program. Contemporary Issues in Technology and Teacher Education, 15(1), 14-43.

Philippou, G., \& Christou, C. (2002). A study of the mathematics teaching efficacy belief of a primary teachers. In G. C. Leder, E. Pehkonen, E., \& G. Törner (Eds.), Beliefs: A hidden variable in mathematics education? (pp. 211-231). Netherlands: Kluwer Academic Publishers.

Polit, D. F., \& Beck, C. T. (2006). The content validity index: Are you sure you know what's being reported? Critique and recommendations. Research in Nursing and Health, 29(5), 489-497. https://doi.org/10.1002/nur.20147 
Qian, H., \& Youngs, P. (2016). The effect of teacher education programs on future elementary mathematics teachers' knowledge: A five-country analysis using TEDS-M data. Journal of Mathematics Teacher Education, 19(4), 371-396. https://doi.org/10.1007/s10857-014-9297-0

Ren, Y., Wang, J., \& Hu, L. (2017). Multi-valued stochastic differential equations driven by G-Brownian motion. International Journal of Control, 90(5), 1132-1154.

Sanchez-Franco, M. J., \& Roldán, J. L. (2010). Expressive aesthetics to ease perceived community support: Exploring personal innovativeness and routinised behaviour as moderators in Tuenti. Computers in Human Behavior, 26(6), 1445-1457. https://doi.org/10.1016/j.chb.2010.04.023

Shahbari, J. A. (2017). Mathematical and pedagogical knowledge amongst first- and second-grade in-service and pre-service mathematics teachers. International Journal for Mathematics Teaching and Learning, 18(1), 41-65.

Shi, Q. (2016). Interrelationships among teacher self-efficacy, collective teacher efficacy, and teachers' pedagogical content knowledge. Unpublished doctoral dissertation, University of Nevada, Las Vegas.

Shirvani, H. (2015). Pre-service elementary teachers' mathematics content knowledge: A predictor of sixth graders' mathematics performance. International Journal of Instruction, 8(1), 132-142. Retrieved from http://www.scopus.com/inward/ record.url?eid=2-s2.0-84921932931\&partnerID=tZOtx3y1

Simsek, N., \& Boz, N. (2016). Analysis of pedagogical content knowledge studies in the context of mathematics education in Turkey: A meta-synthesis study. Educational Sciences: Theory \& Practice, 16(3), 799-826. https://doi.org/10.12738/ estp.2016.3.0382

Swars, S., Hart, L. C., Smith, S. Z., Smith, M. E., \& Tolar, T. (2007). A longitudinal study of elementary pre-service teachers' mathematics beliefs and content knowledge. School Science and Mathematics, 107(8), 325-335. https://doi .org/10.1111/j.1949-8594.2007.tb17797.x

Swars, S. L., Smith, S. Z., Smith, M. E., \& Hart, L. C. (2009). A longitudinal study of effects of a developmental teacher preparation program on elementary prospective teachers' mathematics beliefs. Journal of Mathematics Teacher Education, 12(1), 47-66. https://doi.org/10.1007/s10857-008-9092-x

Tatto, M. T., Peck, R., Schwille, J., Bankov, K., Senk, S. L., Rodriguez, M., Ingvarson, L., Reckase, M., \& Rowley, G. (2012). Policy, practice, and readiness to teach primary and secondary mathematics in 17 countries: Findings from the IEA Teacher Education and Development Study in Mathematics (TEDS-M-M). International Association for the Evaluation of Educational Achievement. Retrieved from http://eric.ed.gov/?id=ED542380

Tatto, M. T., Rodriguez, M., \& Lu, Y. (2015). The influence of teacher education on mathematics teaching knowledge: Local implementation of global ideals. Promoting and Sustaining a Quality Teacher Workforce, 27(1), 279-331. https:// doi.org/10.1108/IJBM-07-2013-0069 
Tatto, M. T., Schwille, J., Senk, S., Ingvarson, L., Peck, R., \& Rowley, G. (2008). Teacher Education and Development Study in Mathematics (TEDS-M): Policy, practice, and readiness to teach primary and secondary mathematics. Conceptual framework. East Lansing, MI: Teacher Education and Development International Study Center, College of Education, Michigan State University.

Thanheiser, E., Browning, C., Edson, A., Kastberg, S., \& Lo, J.-J. (2013). Building a knowledge base: Understanding prospective elementary teachers' mathematical content knowledge. International Journal for Mathematics Teaching and Learning, 9(July), 1-34.

Toh T. L., Berinderjeet K., \& Koay P. L. (2009). Singapore pre-service secondary mathematics teachers' content knowledge: Findings from an international comparative study. The Mathematics Educator, 1-22.

Venkat, H., \& Spaull, N. (2015). What do we know about primary teachers' mathematical content knowledge in South Africa? An analysis of SACMEQ 2007. International Journal of Educational Development, 41, 121-130. https://doi.org/10.1016/j .ijedudev.2015.02.002

Zulkpli Z., Mohamed M., \& Abdullah A. H. (2017). Assessing mathematics teachers' knowledge in teaching thinking skills. Sains Humanika, 9(1-4), 83-87. https:// doi.org/10.11113/sh.v9n1-4.1129 


\section{APPENDIX}

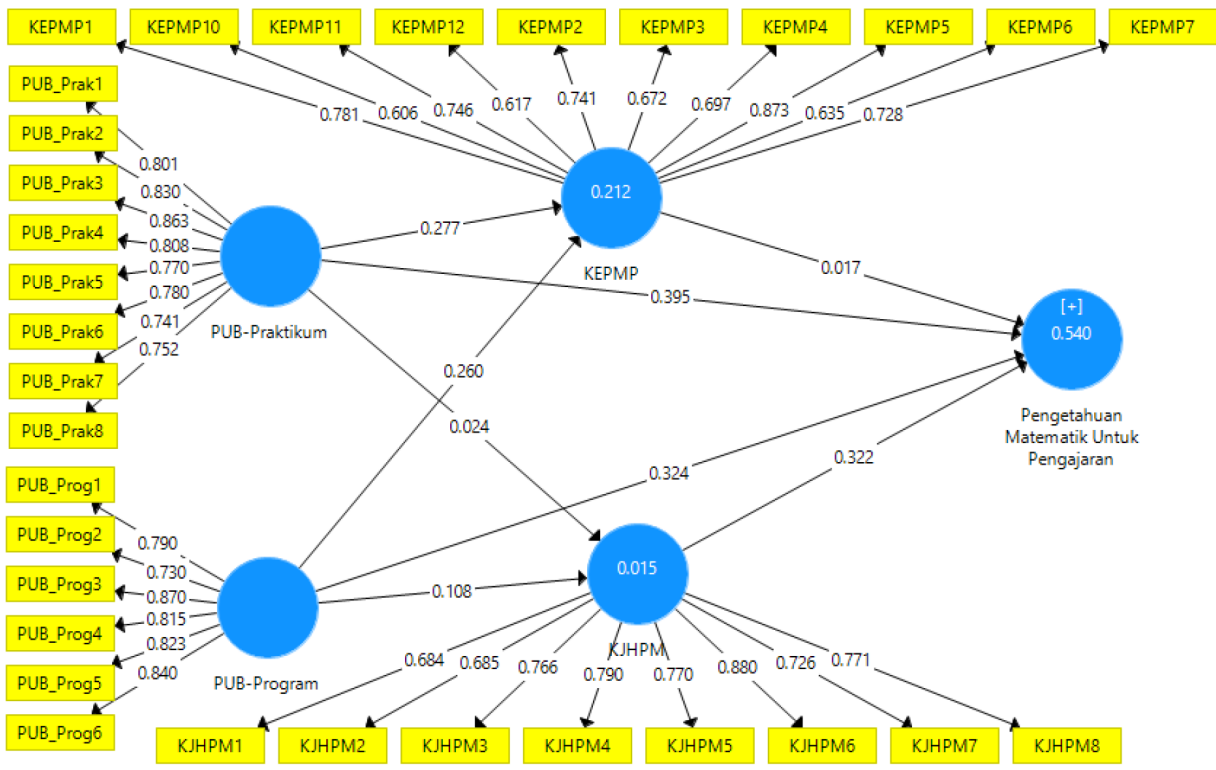

